\title{
The Predictive Value of Non-Invasive Blood Ammonia Level for the Presence of Oesophageal Varices in Patients with Liver Cirrhosis Mohamed Abdelhakeem Aboushady ${ }^{1}$, Arafat Abdelazeem Kassem ${ }^{1}$, Mohamed Saad Eldeen Radwan', Abdou Ragab Ahmed Ismail ${ }^{1 *}$
}

Departments of ${ }^{1}$ Internal Medicine and ${ }^{2}$ Clinical Pathology, Faculty of Medicine, Al-Azhar University

*Correspondence author: Abdou Ragab Ismail, Mobile: (+20)01009042439, E-mail: abdouragab2016417891@ gmail.com

\begin{abstract}
Background: portal hypertension leads to the formation of portosystemic collateral veins in liver cirrhosis. Rupture of esophageal varices is common and can be fatal. Gastroesophageal varices are present in 50\% of patients with cirrhosis. Their presence correlates with the severity of liver disease.

Objective: the aim of this work was to investigate the diagnostic utility of blood ammonia level as a noninvasive predictor for presence of oesophageal varices and correlate it with variceal size in patients with liver cirrhosis.

Patients and Methods: this cross-sectional study was carried out in the department of Internal Medicine, Gastroenterology and Hepatology Unit, Al-Hussein University Hospital. A total of 70 consecutive patients and 20 normal healthy volunteer were included in the study.

Results: There was a highly significant increase in the mean values of ammonia levels, spleen and portal vein diameters in cirrhotic patients with OV in comparison to patients without OV. There was a highly significant decrease in the mean values of haemoglobin in patients with OV in comparison to other patients without OV For detection of OV. There was a highly significant increase in the mean values of serum ammonia in patients with OV in comparison to other patients without OV.

Conclusion: the blood ammonia level may be clinically useful as it correlates with and is an independent predictor for both endoscopic risk signs and risk factors of bleeding, and therefore, it could be used in cirrhotic patients to decrease the number of screening endoscopies they are subjected to.
\end{abstract}

Keywords: Non-Invasive Blood Ammonia Level, Oesophageal Varices, Liver Cirrhosis

\section{INTRODUCTION}

Portal hypertension leads to the formation of portosystemic collateral veins in liver cirrhosis. Rupture of esophageal varices is common and can be fatal. Gastroesophageal varices are present in 50\% of patients with cirrhosis. Their presence correlates with the severity of liver disease. Patients without varices develop them at a rate of $8 \%$ per year ${ }^{(\mathbf{1})}$, and the progression from small to large varices occurs in 10 to $20 \%$ of cases yearly. Variceal hemorrhage occurs at a yearly rate of 5 to $15 \%{ }^{(2)}$.

The most important predictor of hemorrhage is the size of varices, with the highest risk of first hemorrhage (15\% per year) occurring in patients with large varices ${ }^{(3)}$. The risk of first variceal bleeding in patients with largeor medium-sized varices is significantly reduced by betablockers $(30 \%$ in controls vs $14 \%$ in beta blockertreated patients $)^{(4)}$.

On the basis of these studies recent practice guidelines have recommended that all patients with cirrhosis undergo screening upper GI endoscopy to detect esophageal varices at the time of diagnosis and after that, surveillance endoscopies should be performed every 2 to 3 years in cirrhotic patients without varices and that patients with small varices be endoscoped every 1 to 2 years, and annually in the setting of decompensation ${ }^{(5)}$.

Since, the prevalence of medium/large varices is approximately 15 to $25 \%{ }^{(6)}$, the majority of subjects undergoing screening endoscopy either do not have varices or have varices that do not require prophylactic therapy. In other words, a large number of patients will be subjected to unnecessary, invasive procedures.
Therefore, the identification of nonendoscopic, noninvasive methods that can accurately predict esophageal varices, particularly medium/large esophageal varices in cirrhotic patients can helpto identify patients at greatest risk and thereby reduce the necessity of endoscopic screening ${ }^{(6)}$.

\section{AIM OF THE WORK}

The aim of this work is to investigate the diagnostic utility of blood ammonia level as a noninvasive predictor for presence of oesophageal varices and correlate it with variceal size in patients with liver cirrhosis.

\section{PATIENTS AND METHODS}

This cross-sectional study was carried on in the department of Internal Medicine, Gastroenterology and Hepatology Unit, Al Hussein University Hospital. A total of 70 consecutive patients and 20 normal healthy volunteer were included in the study. All subjects were be grouped as group one that comprises 40 patients with liver cirrhosis and endoscopic evidence of esophageal varices, group two that comprises 30 cirrhotic patients without endoscopic evidence of esophageal varices, and group three which included 20 normal healthy volunteer, served as control.

Group 1 was again divided into two subgroups according to the size of esophageal varices, group 1A: Cirrhotic patients with small esophageal varices (F1), group 1B: Cirrhotic patients with medium and large esophageal varices $(\mathrm{F} 2, \mathrm{~F} 3)$. 
Ethical approval and written informed consent:

An approval of the study was obtained from Al- Azhar University academic and ethical committee. Every patient signed an informed written consent for acceptance of the operation.

\section{Patients with the following criteria were excluded from the study.}

- Patients who received endoscopic variceal ligation (EVL) or sclerotherapy, surgery for oesophageal varices, or patients with history of previous or current use of beta blockers.

- Presence of hepatic encephalopathy.

- Active or recent GI bleeding within 4 weeks.

- Portal vein thrombosis on ultrasonography (USG).

- Hepatocellular carcinoma.

- Serum creatinine of $>1.3 \mathrm{mg} / \mathrm{dl}$.

- Patients in whom endoscopy is contraindicated.

\section{All patients included in the study were subjected to: History taking and clinical examination:}

Thorough history taking and clinical examination were done to confirm signs of chronic liver disease and signs of its complications.

\section{1- Laboratory investigations:}

- Complete blood count (CBC).

- Liver profile.

- Kidney function tests including.

- Blood levels of ammonia (NH4) $(\mu \mathrm{mol} / \mathrm{l})$.

2- Abdominal ultrasonography:

Real time abdominal ultrasonography was done. The ultrasonographic examination of the liver included size, echogenicity, parenchyma and focal lesions. Portal vein and biliary system were also examined. Spleen was examined regarding the size and texture. Presence of ascites was evaluated. Other abdominal organs such as kidneys, pancreas and para-aortic lymph nodes were also examined.

\section{3- Upper endoscopy:}

All endoscopies were performed by experienced endoscopists and oesophageal varices were graded according to modified grading system as follows ${ }^{(7)}$ :

- Grade I: Small straight varices confined to the lower third of esophagus.

- Grade II: Moderate sized clubbed varices, with well defined areas of normal mucosa between them forming several distinct vertical cords and confined to the lower half of the oesophagus.

- Grade III: Gross varices, extending into the proximal half of the esophagus which was so large and tortuous that normal mucosa may not be visible in between unless the esophagus is fully distended with air.

- Grade IV: Varices are likely those of grade III but with dilated capillaries on top and hemocysts.
Child Turcotte Pugh Score was calculated for all patients:

Table (1): Child-Turcotte-Pugh Scoring System for Cirrhosis ${ }^{(8)}$.

\begin{tabular}{||l|c|c|c||}
\hline \multicolumn{1}{|c|}{ Variable } & 1 Point & 2 Points & 3 Points \\
\hline Encephalopathy & None & Grade 1-2 & Grade 3-4 \\
\hline Ascites & Absent & $\begin{array}{c}\text { Easily to } \\
\text { controlled }\end{array}$ & $\begin{array}{c}\text { Poorly } \\
\text { controlled }\end{array}$ \\
\hline $\begin{array}{l}\text { Serum Bilirubin } \\
\text { (mg/dL) }\end{array}$ & $<2$ & $2-3$ & $>3$ \\
\hline $\begin{array}{l}\text { Serum Albumin } \\
\text { g/dL) }\end{array}$ & $>3.5$ & $2.8-3.5$ & $<2.8$ \\
\hline Nutrition & Excellent & Good & Poor \\
\hline
\end{tabular}

Child Class $\mathrm{A}=5-6$ points $\quad$ Child Class $\mathrm{B}=7-9$ points

Child Class $\mathrm{C}=10-15$ points $^{\left({ }^{(8)}\right.}$.

\section{Sample collection and measurement of Ammonia:}

- EDTA is the only acceptable anticoagulant because it reduces red cell ammonia production.

- Blood sample was collected from a stasis- free vein of fasting patient.

- Smoking was avoided prior to sample.

- Tubes were filled completely and kept tightly stoppered at all times.

- Tubes were placed immediately on ice and centrifuged at $4^{\circ} \mathrm{C}$.

- Analysis was performed within 30 minutes of venipuncture.

\section{Calculation of the Results}

$\mathrm{A} 1-\mathrm{A} 2=\mathrm{A}$ specimen or A standard or A specimen blank. A specimen final $=$ A specimen - A specimen blank.

Concentration of ammonia in the serum:

Ammonia $(\mu \mathrm{mol} / \mathrm{dl})=$ A spcimen final / A standard $\mathrm{x} 521$.

Blood ammonia level, Child class, platelet count, splenic diameter and platelet count / splenic diameter ratio were compared between two groups of patients with liver cirrhosis and control group.

The sensitivity, specificity and accuracy of blood ammonia level, platelet count, splenic diameter and platelet count to splenic diameter ratio level as non invasive predictors of oesophageal varices were studied by applying the ROC curve to detect the best cut off values with the highest sensitivity and specificity.

The study details were discussed with the patients who fulfilled our criteria of diagnosis of liver cirrhosis in order to get their consent.

\section{Statistical analysis}

Recorded data were analyzed using the statistical package for social sciences, version 20.0 (SPSS Inc., Chicago, Illinois, USA). Quantitative data were expressed as mean \pm standard deviation (SD). Qualitative data were expressed as frequency and percentage. 
The following tests were done:

- Independent-samples t-test of significance was used when comparing between two means.

- Chi-square $\left(\mathrm{x}^{2}\right)$ test of significance was used in order to compare proportions between two qualitative parameters.

- The confidence interval was set to $95 \%$ and the margin of error accepted was set to $5 \%$. The $\mathrm{p}$-value was considered significant as the following:

- Probability (P-value)

- P-value $<0.05$ was considered significant.

- P-value <0.001 was considered as highly significant.

- P-value >0.05 was considered insignificant.

\section{RESULTS}

Table (2) shows the comparison between different studied groups regarding Sex, males in group IA were $14(70 \%)$ and females were $6(30 \%)$, in group IB were $11(55 \%), 9(45 \%)$ respectively, in group II were $16(53.3 \%), 14(46.7 \%)$ respectively and in group III were $8(40 \%), 12(60 \%)$ respectively.

It was found that there was no statistical significant difference between the studied groups regarding sex $(\mathrm{P}>0.05)$.

Table (2): Comparison between different studied groups regarding Sex

\begin{tabular}{|c|c|c|c|c|c|c|c|c|c|c|}
\hline \multirow[t]{3}{*}{$\overline{\text { Sex }}$} & \multicolumn{8}{|c|}{ Groups } & \multirow{2}{*}{\multicolumn{2}{|c|}{ Total }} \\
\hline & \multicolumn{2}{|c|}{ Group IA } & \multicolumn{2}{|c|}{ Group IB } & \multicolumn{2}{|c|}{ Group II } & \multicolumn{2}{|c|}{ Group III } & & \\
\hline & No. & $\%$ & No. & $\%$ & No. & $\%$ & No. & $\%$ & No. & $\%$ \\
\hline Male & 14 & 70.0 & 11 & 55.0 & 16 & 53.3 & 8 & 40.0 & 49 & 54.4 \\
\hline Female & 6 & 30.0 & 9 & 45.0 & 14 & 46.7 & 12 & 60.0 & 41 & 45.6 \\
\hline Total & 20 & 100.0 & 20 & 100.0 & 30 & 100.0 & 20 & 100.0 & 90 & 100.0 \\
\hline $\begin{array}{r}\mathrm{P} \\
\mathrm{X}^{2}\end{array}$ & & & & $\begin{array}{l}3.6 \\
0.3\end{array}$ & & & & & & \\
\hline
\end{tabular}

$\mathrm{X}^{2}=$ Chi square test $\mathrm{P}$ is significant if $\leq 0.05$

Table (3) shows the comparison between different studied groups regarding age, Age in groupIA ranged from 28-64 with mean value 47.00 \pm 10.62 , in group IB ranged from 29-64 with mean value 46.95 \pm 10.62 , in group II ranged from 30-62 with mean value $45.77 \pm 10.61$ and in group III ranged from $28-61$ with mean value $46.75 \pm 10.05$. There was no statistical significant difference between the studied groups regarding age $(\mathrm{p}>0.05)$.

Table (3): Comparison between different studied groups regarding age

\begin{tabular}{||l|c|c|c|c||}
\hline \multirow{2}{*}{ Age } & \multicolumn{4}{c||}{ Groups } \\
\cline { 2 - 5 } & Group IA & Group IB & Group II & Group III \\
\hline Range & $28.00-64.00$ & $29.00-64.00$ & $30.00-62.00$ & $28.00-61.00$ \\
Mean & 47.00 & 46.95 & 45.77 & 46.75 \\
\pm S.D. & \pm 10.62 & \pm 10.62 & \pm 10.61 & \pm 10.05 \\
\hline F & \multicolumn{4}{|c||}{0.080} \\
P & \multicolumn{4}{|c|}{0.971} \\
\hline
\end{tabular}

$\mathrm{F}=$ ANOVA test $\mathrm{P}$ is significant if $\leq 0.05$

Table (4) shows the comparison between different studied groups regarding grade of esophageal varices, it was found that grade of esophageal varices in group 1A was F1 and 50.0\% of the group IB was F2 and 50\% was F3. There was a statistical significant difference between the two subgroups regarding the grade $(\mathrm{p}<0.05)$.

Table (4): Comparison between different studied groups regarding grade of esophageal varices

\begin{tabular}{||c|c|c|c|c|c|c||}
\hline \multirow{2}{*}{$\begin{array}{l}\text { Grade of esophageal } \\
\text { varices }\end{array}$} & \multicolumn{3}{|c|}{ Group IA } & \multicolumn{2}{c||}{ Group IB } & \multicolumn{2}{c|}{ Total } \\
\cline { 2 - 7 } & No. & \% & No. & \% & No. & \% \\
\hline F1 & 20 & 100.0 & 0 & 0.0 & 20 & 50.0 \\
\hline F2 & 0 & 0.0 & 10 & 50.0 & 10 & 25.0 \\
\hline F3 & 0 & 0.0 & 10 & 50.0 & 10 & 25.0 \\
\hline Total & 20 & 100.0 & 20 & 100.0 & 40 & 100.0 \\
\hline $\mathrm{X}^{2}$ & \multicolumn{7}{|c|}{40.000} \\
P & \multicolumn{7}{|c|}{$0.0001 *$} \\
\hline
\end{tabular}

$\mathrm{X}^{2}=$ Chi square test, $\quad \mathrm{P}$ is significant if $\leq 0.05 \quad *$ significant difference. Table (5) shows the comparison between different studied groups regarding $\mathrm{Hb}$ and TLC. $\mathrm{Hb}$ in group IA ranged from 9.50-11.70 with mean value $10.82 \pm 0.72$, in group IB ranged from 9.60-12.00 with mean value 10.74 \pm 0.71 , in group II ranged from 9.50-12.0 with 
mean value $10.53 \pm 0.77$ and in group III ranged from $10.70-12.30$ with mean value $11.48 \pm 0.52$. TLC in group IA ranged from 5.10-7.00 with mean value 6.04 \pm 0.66 , in group IB ranged from 5.00-7.00 with mean value 5.96 \pm 0.57 , in group II ranged from 5.00-6.00 with mean value 5.48 \pm 0.29 and in group III ranged from 5.10-6.00 with mean value $5.53 \pm 0.28$. It was found that the level of $\mathrm{Hb}$ was low in patients group less than control group, also the TLC show statistical significant increase in both group IA and IB $(\mathrm{p}<0.05)$.

Table (5): Comparison between different studied groups regarding $\mathrm{Hb}$ and TLC

\begin{tabular}{|c|c|c|c|c|c|}
\hline & \multicolumn{4}{|c|}{ "Subgroup } & \multirow{2}{*}{$\begin{array}{l}\mathrm{F} \\
\mathrm{P}\end{array}$} \\
\hline & Group IA & Group IB & Group II & Group III & \\
\hline $\begin{array}{l}\mathbf{H b} \\
\text { Range } \\
\text { Mean } \pm \text { S.D. }\end{array}$ & $\begin{array}{l}9.50-11.70 \\
10.82 \pm 0.72\end{array}$ & $\begin{array}{l}9.60-12.00 \\
10.74 \pm 0.71\end{array}$ & $\begin{array}{l}9.50-12.00 \\
10.53 \pm 0.77\end{array}$ & $\begin{array}{r}10.70-12.30 \\
11.48 \pm 0.52\end{array}$ & $\begin{array}{c}7.756 \\
0.0001 *\end{array}$ \\
\hline $\begin{array}{l}\text { TLC } \\
\text { Range } \\
\text { Mean } \pm \text { S.D. }\end{array}$ & $\begin{array}{l}5.10-7.00 \\
6.04 \pm 0.66\end{array}$ & $\begin{array}{l}5.00-7.00 \\
5.96 \pm 0.57\end{array}$ & $\begin{array}{l}5.00-6.00 \\
5.48 \pm 0.29\end{array}$ & $\begin{array}{l}5.10-6.00 \\
5.53 \pm 0.28\end{array}$ & $\begin{array}{c}8.519 \\
0.0001 *\end{array}$ \\
\hline
\end{tabular}

$\mathrm{F}=$ ANOVA test, $\mathrm{P}$ is significant if $\leq 0.05, *$ significant difference

Table (6) shows the comparison between different studied groups regarding ALT, AST and serum albumin, there was statistical significant increase in both ALT and AST in group IA and IB more than group II ( $\mathrm{p}<0.05)$, serum albumin show insignificant difference between the studied groups $(\mathrm{P}>0.05)$.

Table (6): Comparison between different studied groups regarding ALT, AST and serum albumin

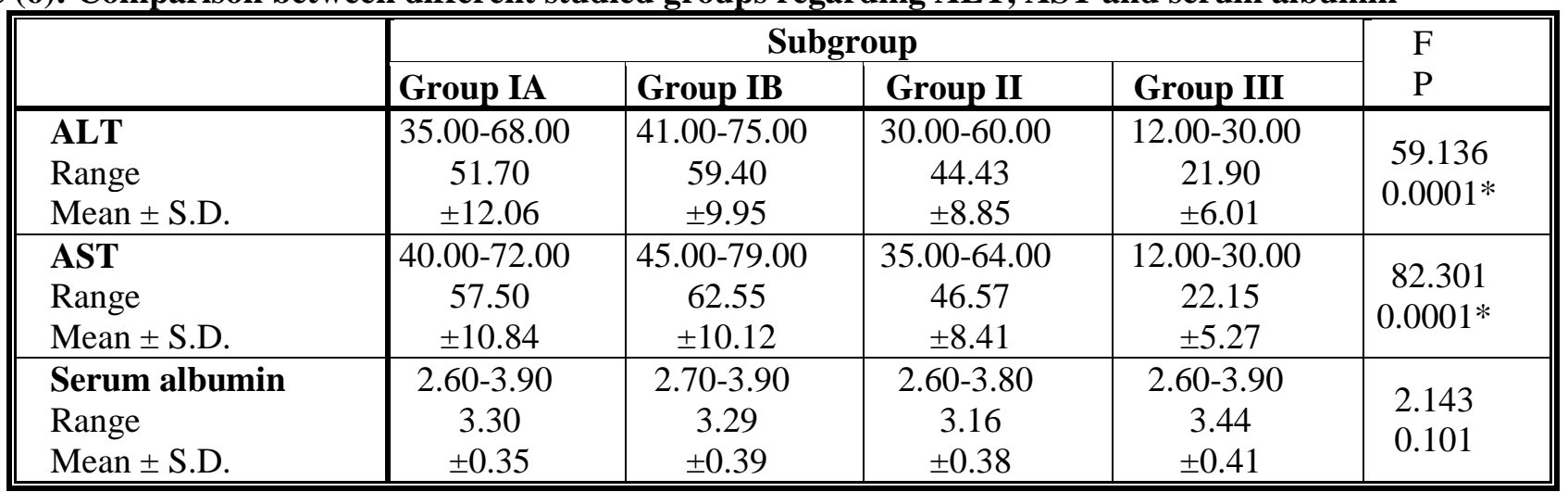

$\mathrm{F}=\mathrm{ANOVA}$ test, $\mathrm{P}$ is significant if $\leq 0.05, *$ significant difference

Table (7) shows the comparison between different studied groups regarding total bilirubin and direct bilirubin, total bilirubin in group IA ranged from 1.60-3.50 with mean value 2.47 \pm 0.66 , in group IB ranged from 1.60-3.50 with mean value $2.35 \pm 0.56$, in group II ranged from 1.20-2.90 with mean value 2.00 \pm 0.59 and in group III ranged from $1.60-2.00$ with mean value $1.77 \pm 0.13$. Direct bilirubin in group IA ranged from $0.60-1.20$ with mean value $0.90 \pm 0.18$, in group IB ranged from $0.60-1.30$ with mean value $0.94 \pm 0.23$, in group II ranged from $0.60-1.20$ with mean value $1.02 \pm 0.19$ and in group III ranged from $0.30-.90$ with mean value $0.60 \pm 0.19$. It was found that there was statistical significant increase in both total and direct bilirubin in both subgroup IA and IB more than group II and III (P <0.01).

Table (7): Comparison between different studied groups regarding total bilirubin and direct bilirubin

\begin{tabular}{||l|l|l|l|l|l||}
\hline \hline & \multicolumn{4}{|c|}{ Subgroup } & F \\
\cline { 2 - 5 } & Group IA & Group IB & Group II & Group III & P \\
\hline Total bilirubin & $1.60-3.50$ & $1.60-3.50$ & $1.20-2.90$ & $1.60-2.00$ & 7.296 \\
Range & $2.47 \pm 0.66$ & $2.35 \pm 0.56$ & $2.00 \pm 0.59$ & $1.77 \pm 0.13$ & $0.0001^{*}$ \\
Mean \pm S.D. & $0.60-1.20$ & $0.60-1.30$ & $0.60-1.20$ & $0.30-.90$ & 19.953 \\
\hline Direct bilirubin & $0.90 \pm 0.18$ & $0.94 \pm 0.23$ & $1.02 \pm 0.19$ & $0.60 \pm 0.19$ & $0.0001^{*}$ \\
Range & Mean \pm S.D. & &
\end{tabular}

$\mathrm{F}=$ ANOVA test, $\mathrm{P}$ is significant if $\leq 0.05, *$ significant difference

Table (8) shows the comparison between different studied groups regarding serum alpha-fetoprotein, in group IA ranged from 6.34-35.60 with mean value 15.19 \pm 9.16 , in group IB ranged from 6.14-36.80 with mean value 
18.09 \pm 9.48 , in group II ranged from 5.32-37.80 with mean value 16.34 \pm 7.73 and in group III ranged from 3.10-4.00 with mean value $3.49 \pm 0.28$. There was statistical significant increase in serum alpha -feto protein in group IA, IB and II more than the control group $(\mathrm{p}<0.01)$.

Table (8): Comparison between different studied groups regarding serum alpha -fetoprotein

\begin{tabular}{|l|l|l|l|l||}
\hline \multirow{2}{*}{} & \multicolumn{4}{|c|}{ Subgroup } \\
\cline { 2 - 5 } & Group IA & Group IB & Group II & Group III \\
\hline $\begin{array}{l}\text { Serum alpha- fetoprotein } \\
\text { Mean } \pm \text { S.D. }\end{array}$ & $15.19 \pm 2.16$ & $18.09 \pm 2.48$ & $16.34 \pm 3.73$ & $3.49 \pm 0.28$ \\
\hline & \multicolumn{5}{|c|}{$\begin{array}{c}15.497 \\
0.0001 *\end{array}$} \\
\hline
\end{tabular}

$\mathrm{F}=$ ANOVA test, $\mathrm{P}$ is significant if $\leq 0.05, *$ significant difference

Table (9), shows the comparison between before and after endoscoy in group IB regarding ammonia level, it was found that the level of ammonia before endoscoy was $51.95 \pm 6.87$, while after endoscoy was $32.6 \pm 5.65$, there was a significant decrease in ammonia level $(\mathrm{p}<0.01)$.

Table (9): Comparison between before and after endoscoy in group IB regarding ammonia level

\begin{tabular}{||c|c|c||}
\hline \multirow{2}{*}{ Ammonia $(\boldsymbol{\mu m o l} / \mathbf{l})$} & Gefore & After \\
\cline { 2 - 3 } & $40.00-64.00$ & $28-48$ \\
Range & $51.95 \pm 6.87$ & $32.6 \pm 5.65$ \\
Mean \pm S.D. & \multicolumn{3}{|c||}{} \\
\hline & 4.98 \\
& $0.002 *$ \\
\hline
\end{tabular}

Table (10) shows the comparison between different studied groups regarding, spleen diameter and P.V. diameter, Spleen diameter in group IA ranged from 14.00-22.00 with mean value 18.40 \pm 2.33 , in group IB ranged from 15.0022.00 with mean value $19.05 \pm 2.33$, in group II ranged from $12.00-16.00$ with mean value $14.03 \pm 1.33$ and in group III ranged from 12.00-14.00 with mean value 13.10 \pm 0.85 . P.V. diameter in group IA ranged from 10.00-18.00 with mean value 14.05 \pm 2.61 , in group IB ranged from 11.00-19.00 with mean value 15.20 \pm 2.65 , in group II ranged from 10.0016.00 with mean value $12.50 \pm 1.98$ and in group III ranged from 8.30-11.00 with mean value 9.99 \pm 0.90 . There was highly significant increase in both group IA and IB more than group II and III $(\mathrm{P}<0.01)$. There was statistical significant difference between different studied groups regarding spleen diameter and P.V. diameter.

Table (10): Comparison between different studied groups regarding spleen diameter and P.V. diameter

\begin{tabular}{|c|c|c|c|c|c|}
\hline & \multicolumn{4}{|c|}{ "Subgroup } & \multirow{2}{*}{$\begin{array}{l}F \\
P\end{array}$} \\
\hline & Group IA & Group IB & Group II & Group III & \\
\hline $\begin{array}{l}\text { Spleen diamter } \\
\text { Range } \\
\text { Mean } \pm \text { S.D. }\end{array}$ & $\begin{array}{r}14.00-22.00 \\
18.40 \pm 2.33\end{array}$ & $\begin{array}{r}15.00-22.00 \\
19.05 \pm 2.33\end{array}$ & $\begin{array}{r}12.00-16.00 \\
14.03 \pm 1.33\end{array}$ & $\begin{array}{r}12.00-14.00 \\
13.10 \pm 0.85\end{array}$ & $\begin{array}{c}61.968 \\
0.0001 *\end{array}$ \\
\hline $\begin{array}{l}\text { P.V. diameter } \\
\text { Range } \\
\text { Mean } \pm \text { S.D. }\end{array}$ & $\begin{array}{r}10.00-18.00 \\
14.05 \pm 2.61\end{array}$ & $\begin{array}{r}11.00-19.00 \\
15.20 \pm 2.65\end{array}$ & $\begin{array}{r}10.00-16.00 \\
12.50 \pm 1.98\end{array}$ & $\begin{array}{r}8.30-11.00 \\
9.99 \pm 0.90\end{array}$ & \begin{tabular}{|c|}
22.463 \\
$0.0001 *$ \\
\end{tabular} \\
\hline
\end{tabular}

$\mathrm{F}=$ ANOVA test,$\quad \mathrm{P}$ is significant if $\leq 0.05, *$ significant difference

Table (11) shows the comparison between different studied groups regarding Ascites, Cases without ascites was more that cases with ascites in all groups, in group IA was 16(80\%), in group IB was 13(65\%), in group II was $26(86.7 \%)$ and in group III was $20(100 \%)$. There was a significantly increase in ascites in group IB more than IA more than group II ( $\mathrm{p}<0.01)$. 
Table (11): Comparison between different studied groups regarding Ascites

\begin{tabular}{|c|c|c|c|c|c|c|c|c|}
\hline \multirow{3}{*}{ Ascites } & \multicolumn{8}{|c|}{ "Subgroup } \\
\hline & \multicolumn{2}{|c|}{ Group IA } & \multicolumn{2}{|c|}{ Group IB } & \multicolumn{2}{|c|}{ Group II } & \multicolumn{2}{|c|}{ Group III } \\
\hline & No. & $\%$ & No. & $\%$ & No. & $\%$ & No. & $\%$ \\
\hline No & 16 & 80.0 & 13 & 65.0 & 26 & 86.7 & 20 & 100.0 \\
\hline Yes & 4 & 20.0 & 7 & 35.0 & 4 & 13.3 & 0 & 0.0 \\
\hline Total & 20 & 100.0 & 20 & 100.0 & 30 & 100.0 & 20 & 100.0 \\
\hline $\begin{array}{c}X^{2} \\
P\end{array}$ & & & & $\begin{array}{r}9.2 \\
0.02 \\
\end{array}$ & & & & \\
\hline
\end{tabular}

$\mathrm{X}^{2}=$ Chi square test, $\mathrm{P}$ is significant if $\leq 0.05, *$ significant difference

Table (12) shows comparison between different studied groups regarding Child Pugh classification. Most of patients in group IA were Child c 9(45\%), Most of patients in group II were Child A 13(43.3\%) Most of patients in group IB were Child B 12(40\%). There was no statistical significant difference between different studied groups regarding Child Pugh classification $(\mathrm{P}>0.05)$.

Table (12): Comparison between different studied groups regarding Child Pugh classification

\begin{tabular}{|c|c|c|c|c|c|c|}
\hline \multirow{3}{*}{$\begin{array}{l}\text { Child Pugh } \\
\text { classification }\end{array}$} & \multicolumn{6}{|c|}{ Subgroup } \\
\hline & \multicolumn{2}{|c|}{ Group IA } & \multicolumn{2}{|c|}{ Group IB } & \multicolumn{2}{|c|}{ Group II } \\
\hline & No. & $\%$ & No. & $\%$ & No. & $\%$ \\
\hline $\mathrm{A}$ & 5 & 25.0 & 5 & 25.0 & 13 & 43.3 \\
\hline B & 6 & 30.0 & 8 & 40.0 & 12 & 40.0 \\
\hline $\mathrm{C}$ & 9 & 45.0 & 7 & 35.0 & 5 & 16.7 \\
\hline Total & 20 & 100.0 & 20 & 100.0 & 30 & 100.0 \\
\hline $\begin{array}{l}\mathrm{P} \\
\mathrm{X} 2\end{array}$ & & & & & & \\
\hline
\end{tabular}

$\mathrm{X}^{2}=$ Chi square test, $\mathrm{P}$ is significant if $\leq 0.05$

Table (13) show the sensitivity, specificity and accuracy of blood ammonia in predict oesophageal varices, it was found that the sensitivity of ammonia in predict oesphageal varices was $92.5 \%$, specificity was $90.0 \%$ and accuracy was $91.0 \%$.

Table (13): Sensitivity, specificity and accuracy of blood ammonia in predict oesophageal varices

\begin{tabular}{|c|c|c|c|c||}
\hline \multirow{2}{*}{ Area } & \multirow{2}{*}{ P value } & \multirow{2}{*}{ Cut off value } & \multicolumn{2}{|c||}{ Asymptotic 95\% Confidence Interval } \\
\cline { 4 - 5 } & & & Lower Bound & Upper Bound \\
\hline .904 & $0.0001 *$ & 30.0 & .842 & .967 \\
\hline Sensitivity & & 92.5 \\
Specificity & & 90.0 & \\
Accuracy & & 91.0 & \\
\hline
\end{tabular}

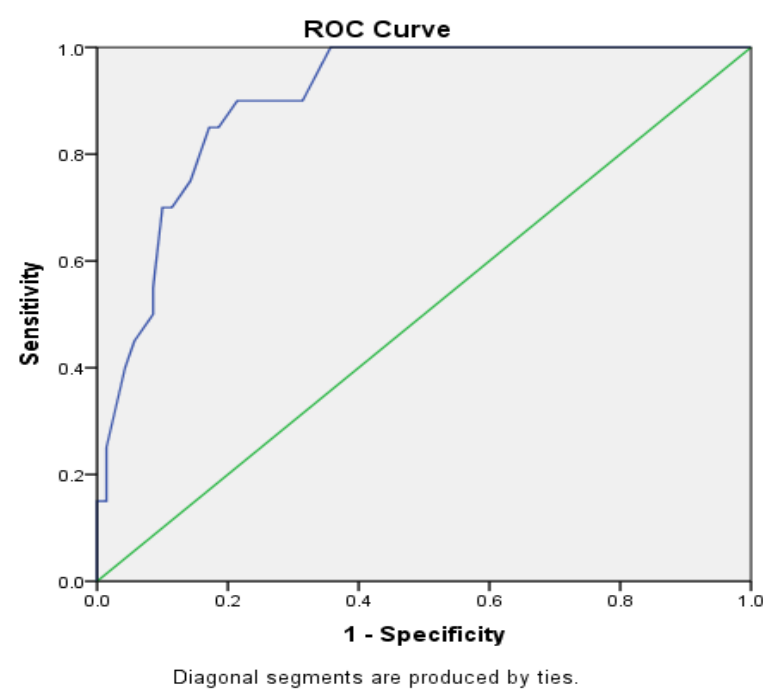

Figure (1): ROC Curve to predict Sensitivity, specificity and accuracy ofblood ammonia in predict oesophageal varices 


\section{DISCUSSION}

In this study the demographic data of our patients (age and sex) was matched in the different studied groups, there was no statistically significant difference as regard to these parameters between all groups; these results were advantageous to eliminate the effect of age and sex on the blood ammonia level. These results were agreement with the study performed by Brusilow ${ }^{(9)}$ who documented no significant difference between cirrhotic patientswithand those without esophageal varicesregarding age,in this study the age ranges (17-74) and the mean age was around 45 years, also there was no significant difference between the studied groups regarding age.

Regarding blood picture in our study, there was a significant decrease in the mean value of hemoglobin level in patientgroups in comparison to the control group. This result was in agreement with Wang et al. ${ }^{(\mathbf{1 0 )}}$ who reported that, hemoglobin levels were significantly decreased in patients with OV. The TLC in our study showed a significant increase in both group IA and IB (with liver cirrhosis and endoscopic evidence of esophageal varices) more than patients without varcies and the control group. These results were agreement with the results in Wang study, in this study the TLC was significantly increased in patients with OV.

In this study, there was a significant increase in the mean values of ALT, AST in cirrhotic patients with evidence of OV in comparison to patients without varices, the two patient groups show a significant increase in ALT and AST more than the control group. These results were in agreement with the study performed by Tafarel $\boldsymbol{e} t$ al. ${ }^{(11)}$ who found that ALT and AST levels significantly increased in patients with large varices.

Impairment of liver function and uptake leads to the accumulation of ammonia in splanchnic vessels, resulting in their vasodilatation and an increased portal blood flow generating portal hypertension ${ }^{(\mathbf{1 2})}$.It is known that the hepatic stellate cell activation andaltered function play an important role in the occurrenceof liver fibrosis and portal hypertension ${ }^{(13)}$.

High ammonia levels may have detrimental effects on stellate cell function ${ }^{(9)}$. Recently, it has been reported that abnormally high ammonia levels causesignificant alteration in proliferation and metabolic activity of stellate cells in vitro. Therefore, elevation of ammonia seems to be part of a vicious circle. It results from the presence of portal hypertension and portosystemic collaterals and leads to a further increase in portal hypertension ${ }^{(14)}$.

When the cirrhotic patients were subgrouped according to the size of varices into group 1A (small esophageal varices), and group 1B (medium and large esophageal varices, the mean ammonia concentration in group $1 \mathrm{~A}$ was $47.10 \pm 6.22 \mathrm{umol} / \mathrm{L}$ and in group $1 \mathrm{~B}$ was $51.95 \pm 6.87 \mathrm{umol} / \mathrm{L}$, there was no significant difference between the two groups. Blood ammonia, the newly suggested non-invasive marker of esophageal varices showed significant difference between small esophageal varices group (group 1A) and medium and large esophageal varices group (group $1 \mathrm{~B})(\mathrm{P}=0.0001)$ in the present study. Also in Spearman's correlation coeffiecent test, blood ammonia level was correlated with Portal venous diameter $(P=0.000)$. Degree of correlation in the present study was comparable with those reported by Tarantino et al. ${ }^{(11)}$, where $\mathrm{P}$ value was 0.001 .

In our study, on ultrasound examination, cephalocaudal splenic measurement of whole patients with oesophagealvarices was $18.40 \pm 2.33 \mathrm{~cm}$ in group $1 \mathrm{~A}, 19.05 \pm 2.33 \mathrm{~cm}$ in group $1 \mathrm{~B}, 14.03 \pm 1.33 \mathrm{~cm}$ in the group 2 (without oesophagealvarices) while the cephalocaudal splenic measurement was $13.10 \pm 0.85 \mathrm{~cm}$ in the control group, $\mathrm{p}=0.0001$. Hong et $_{\text {al }}{ }^{(\mathbf{1 5})}$ in their study in Hong Kong found cephalocaudal splenic measurement of $11.7 \pm 3.2 \mathrm{~cm}$ in the group with oesophagealvarices, and $10.2 \pm 2.8 \mathrm{~cm}$ in the group without oesophagealvarices. Giannini et al. ${ }^{(\mathbf{1 6})}$, in their study in Italy in 2003, found a cutoff point of platelet count for presence of varices was $112,000, p=0.0001$ and splenic diameter $>12.1 \mathrm{~cm}, \mathrm{p}=0.0007$. Mohanty et al. ${ }^{(17)}$ found an anteroposterior splenic measurement of $7.6 \pm$ $1.2 \mathrm{~cm}$ in normal subjects and $12.7 \pm 2.1 \mathrm{~cm}$ among patients with liver cirrhosis. Schepis $\boldsymbol{e t} \boldsymbol{a l} .^{(\mathbf{1 8})}$ in Italy found a mean anteroposterior splenic measurement of $16.3 \pm 2.7 \mathrm{~cm}$ in the group with oesophagealvarices, and $13.9 \pm 2.5 \mathrm{~cm}$ in the group without oesophageal varices. This difference in splenic size may be due to racial, genetic, and anatomical differences.Our results regarding splenic size were in agreement with the studies done by Wadawan et al. ${ }^{\left({ }^{(9)}\right)}$ and Mandal et $\boldsymbol{a l} .{ }^{(\mathbf{( 2 )})}$ whose found that there wasstatistically significant relationship between increased splenic diameters and presence of OV.

In our study, the mean portal vein diameter in patients with oesophageal varices was $14.05 \pm 2.61 \mathrm{~mm}$ in group 1A, $15.20 \pm 2.65 \mathrm{~mm}$ in group $1 \mathrm{~B}$, while that in the group without oesophageal varices ( group 2), while in the control group (group 3) was $9.99 \pm 0.90 \mathrm{~mm}$, $\mathrm{p}=0.0001$. These results collaborated with Mohanty $\boldsymbol{e t}$ al. ${ }^{(17)}$ who found that the mean portal vein diameter of $7 \pm 1$ $\mathrm{mm}$ among normal subjects and $12 \pm 2 \mathrm{~mm}$ among cirrhotic patients. Hong et al. ${ }^{(15)}$, in their study, found a portal vein diameter was $11.5 \pm 2.40 \mathrm{~mm}$ among patients with oesophagealvarices, and $10.5 \pm 2.60 \mathrm{~mm}$ among patients without oesophagealvarices. Schepis et al. ${ }^{(18)}$ found a portal vein diameter of $13.82 \pm 2.1 \mathrm{~mm}$, among patients with oesophagealvarices and $12.33 \pm 2.04 \mathrm{~mm}$ among patients without oesophagealvarices. Prihatini $\boldsymbol{e t}$ $\boldsymbol{a l} \mathbf{~}^{(21)}$ concluded in their study that portal vein size $1.2-\mathrm{cm}$ ultrasound gives the evidence of presence of oesophagealvarices. Fernandez $\boldsymbol{e t} \boldsymbol{a l}^{(\mathbf{( 2 2 )}}$ concluded in their study that portal vein size on ultrasound independently associated with varices.

Regarding Child Pugh classification in our study, most patients in group IA were Child C (45.0\%) and most patients in group IB were Child B and C (75.0\%) while 
in group II the majority were class A and B (83.0\%). This came in agreement with the study done by Madhotra $\boldsymbol{e t}$ $\boldsymbol{a l} .{ }^{(23)}$ and Burton et $\boldsymbol{a l} .{ }^{(24)}$ whose found that most patients with OV were Child B and C.

On performing ROC curve to determine the cut off value of blood ammonia to predict the varcies it was found that the blood ammonia level at cutoff value $>40 \mathrm{umol} / \mathrm{L}$ had a sensitivity $92.5 \%$ and specificity $90.0 \%$ and accuracy 91.0 in detectingOV. Other studies have been performed on this point. El-Hefny $\boldsymbol{e t}$ al. ${ }^{(\mathbf{2 5})}$ reported a cutoff value of $77.5 \mathrm{umol} / \mathrm{L}(108.5 \mu \mathrm{g} / \mathrm{dL})$ ammonia with $100 \%$ sensitivity and $95 \%$ specificity for the detection of EV, whereas Tarantino et al. ${ }^{(11)}$ reported a different cutoff value of $42 \mathrm{umol} / \mathrm{L}(58.8 \mu \mathrm{g} / \mathrm{dL})$ with sensitivity $97 \%$ and specificity $43 \%$.Blood ammonia level more than $67 \mathrm{umol} / \mathrm{L}$ had $46.2 \%$ sensitivity, $97.7 \%$ specificity, 75\% PPV and 92.4\% NPV in detecting large oesophagealvarices(grade III and IV varices) in patients with liver cirrhosis. Previous study done by Khondaker et al. ${ }^{(26)}$ found that blood ammonia levelsat $\geq 63$ umol/Lhad a sensitivity of $95 \%$ and specificity of $50 \%$ in detecting large oesophageal varices in patients with cirrhosis.

On comparing the group 1B before and after endoscoy, it was found that there was a significant decrease in ammonia level $(\mathrm{p}<0.05)$.

\section{CONCLUSION}

This study demonstrates on a sufficiently large scale the strict correlation between NH4 levels and portosystemic collateral channels that carry blood away from the portal venous system to the general circulation. The blood ammonia level may be clinically useful as it correlates with and is an independent predictor for both endoscopic risk signs and risk factors of bleeding, and therefore, it could be used in cirrhotic patients to decrease the number of screening endoscopies they are subjected to.

\section{RECOMMENDATIONS}

- Validation study including a larger number of patients will be required to confirm the results of this study and the possibility of its application aiming to reduce number of unnecessary endoscopies.

- Future studies are recommended to investigate the correlation between other parameters and the presences of OV.

\section{REFERENCES}

1. Groszmann RJ, Bosch J, Grace ND, Conn HO, GarciaTsao G, Navasa M, Alberts J, Rodes J, Fischer R and Bermann M (2005):Beta-blockers to prevent gastroesophagealvarices in patients with cirrhosis. N Engl J Med., 353(21): 2254- 2261.

2. Cales P, Desmorat H, Vinel JP, Caucanas JP, Ravaud A, Gerin P, Brouet P and Pascal JP (1990):Incidence of large oesophagealvarices in patients with cirrhosis: Application to prophylaxis of first bleeding. Gut, 31(11):1298-302.
3. North Italian Endoscopic Clubfor the Study and Treatment of Esophageal Varices (1988): Prediction of the first variceal hemorrhage in patients with cirrhosis of the liver and esophageal varices: a prospective multicenter study. N Engl J Med., 319(15):983-989.

4. D'Amico G, Pagliaro $\mathrm{L}$ and Bosch $\mathbf{J}$ (1999): Pharmacological treatment of portal hypertension: an evidence-based approach. Semin Liver Dis., 19(4):475505 .

5. D'Amico G, Garcia-Tsao $G$ and Cales $P$ (2001):Diagnosis of portal hypertension: how and when. In: de Franchis R (ed): Portal hypertension III. proceedings of the third Baveno international consensus workshop on definitions, methodology and therapeutic strategies. $3^{\text {rd }} \mathrm{ed}$. Oxford, UK: Blackwell Science,Pp.36-64.

6. Pagliaro L, D'Amico G and Pasta L (1994): Portal hypertension in cirrhosis: natural history. In: Bosch J, and Groszmann RJ (eds): Portal hypertension pathophysiology and treatment. Oxford, UK: Blackwell Scientific,Pp.72-92.

7. De Franchis $\mathbf{R}$ (2005): Evolving consensus in portal hypertension report of the Baveno IV consensus workshop on methodology of diagnosis and therapy in therapy in portal hypertension. J Hepatol., 43(1):167-176.

8. Kaplan DE, Dai F, Aytaman A et al.(2015): Development and performance of an algorithm to estimate the ChildTurcotte-Pugh score from a National Electronic Healthcare database. ClinGastroenterol Hepatol.,13:2333-41.e1-6.

9. Brusilow SW, Koehler RC, Traystman RJ and Cooper A (2010): Astrocyte glutamine synthetase: importance in hyperammonemic syndromes and potential target for therapy. Neurotherapeutics, 7(4):452-470.

10.Wang C, Han J, Xiao L, Jin CE, Li DJ and Yang Z (2015): Efficacy of vasopressin/ terlipressin and somatostatin/ octreotide for the prevention of early varicealrebleeding after the initial control of bleeding: a systematic review and meta-analysis. Hepatol Int.,9(1):120129.

11. Tarantino G, Citro V, Esposito P, Giaquinto S, de Leone A, Milan G, Tripodi FS, Cirillo $M$ and Lobello $R$ (2009):Blood ammonia levels in liver cirrhosis: a clue for the presence of portosystemic collateral veins. BMC Gastroenterol., 9:21-26.

12.Dooley J, Lok A and Heathcote J (2011):Sherlock's diseases of the liver and biliary system. 13th ed. USA: John Wiley \& Sons Ltd.https://www.wiley.com/en$\mathrm{id} /$ Sherlock\% 27s+Diseases+of+the+Liver+and+Biliary $+\mathrm{S}$ ystem\%2C+13th+Edition-p-9781119237648

13.Schuppan D and Kim YO (2013):Evolving therapies for liver fibrosis. J Clin Invest., 123(5):1887-1901.

14. Tivers MS, Handel I, Gow AG, Lipscomb VJ, Jalan R and Mellanby RJ (2014):Hyperammonemia and systemic inflammatory response syndrome predicts presence of hepatic encephalopathy in dogs with congenital portosystemic shunts. PLoS One, 9(1):e82303.

15. Hong WD, Dong LM, Jiang ZC, Zhu QH and Jin SQ (2011): Prediction of large esophageal varices in cirrhotic patients using classification and regression tree analysis. Clinics, 66(1):119-124.

16. Giannini E, Botta F, Borro P, Risso D, Romagnoli P, Fasoli A, Mele MR, Testa E, Mansi C, Savarino V and Testa R (2003): Platelet count/spleen diameter ratio: proposal and validation of a non-invasive parameter to 
predict the presence of oesophagealvarices in patients with liver cirrhosis. Gut, 52(8):1200-1205.

17. Mohanty R, Mohapatra N, Malla A, Naik J, Mohanty B, Meher M, Swaroop S and Thatoi PK (2017):Correlation of portal vein diameter and splenic size with oesophagealvarices in cirrhosis of liver. Alcohol, 36:72.

18. Schepis $F$, Cammà $C$, Niceforo $D$, Magnano $A$, Pallio $S$, Cinquegrani M, D'amico G, Pasta L, Craxì A, Saitta A and Raimondo G (2001): Which patients with cirrhosis should undergo endoscopic screening for esophageal varices detection? Hepatology, 33(2):333-338.

19. Wadawan M, Dubey S, Sharma BC and Sarin SK (2006): Hepatic venous pressure gradient in cirrhosis: correlation with the size of varices, bleeding ascites and child's status. Dig Dis Sci., 51(12):2264-2269.

20. Mandal L, Mandal SK, Bandyopadhyay D and Datta S (2011): Correlation of portal vein diameter and splenic size with gastro-oesophagealvarices in cirrhosis of liver. JIACM., 12(4):266-270.

21.Prihatini J, Lesmana LA, Manan $C$ and Gani RA (2005):Detection of esophageal varices in liver cirrhosis using noninvasive parameters. Acta Med Indones., 37(3):126-131.
22.Fernandez M, Mejias M, Garcia-Pras E, Gallego J, Pell N, Ramirez M, Naranjo-Suarez $S$ and BarrachinaCatala A (2016): Pathogenesis of portal hypertension: extrahepatic mechanisms. CurrHepatol Rep., 15(3):199207.

23. Madhotra R, Mulcahy HE, Willner I and Reuben A (2002):Prediction of esophageal varices in patients with cirrhosis. J ClinGastroenterol., 34(1):81-85.

24. Burton JR Jr, Liangpunsakul S, Lapidus J, Giannini E, Chalasani Nand Zaman A (2007): Validation of a multivariate model predicting presence and size of varices. J ClinGastroenterol., 41(6):609-615.

25.El-Hefny N, Hareedy $M$ and Abdel-Aal R (2013):Blood ammonia level and other non-invasive parameters as indicators of portosystemic collaterals in cirrhotic patients. Master Thesis: Assiut University.https://www.ncbi.nlm.nih.gov/pmc/articles/PM C6087568/

26. Khondaker MFA, Ahmad N, Al-Mahtab M and Sumi SA (2013):Correlation between blood ammonia level and esophageal varices in patients with cirrhosis of liver. Euroas J Hepato-Gastroenterol., 3(1):10-14. 